\title{
Hrvatski alkemičari tijekom stoljeća [Croatian alchemists within centuries]
}

\author{
Editors: Nenad Trinajstić, Goran Bukan \\ Reviewers: Leo Klasinc, Erna Banić-Pajnić \\ Published by: Croatian Academy of Sciences and Arts; Školska knjiga d.d., Zagreb, 2017 \\ 232 pages 。 ISBN 978-953-0-61195-5
}

Review by: Astrid Gojmerac Ivšić

W ithin the general public and even among some scientists, the mere notion of alchemy typically invokes associations to some ancient and mystical discipline connected with magic and occultism, without any particular importance in the development of modern science and civilization. Nevertheless, if one explores the history of alchemy beyond common notion, he reveals the whole new world of science and philosophy and finds that many modern scientific disciplines and principles are deeply rooted in alchemy, which means that it cannot be easily neglected nor disregarded in the history of science. The book entitled "Hrvatski alkemičari tijekom stoljeća" (in English: "Croatian alchemists within centuries") by Snježana Paušek-Baždar helps to shed some light on the true meaning and importance of alchemy in western civilization, with particular focus on the alchemists in Croatia, which are found to be prolific and in line with European alchemists of their time. As such, this is the first book that systematically analyses alchemy in Croatia thus bringing some forgotten knowledge again to the surface.

In the introductory part of the book, the author notes that in the research of almost nineteen century long history of alchemy, one needs to put distinction between the true alchemists who were led by scientific and philosophical reasoning, and the false alchemists which were mostly impostors and charlatans. The latter principally gave rise to the negative connotations of the alchemy. The author also notes that the main determinants and principles of alchemy science have been largely unknown and incomprehensible to the scientific and general public. Namely, the key goal of alchemists was to find the fundamental starting point for all the matter in the world which was quite nobler goal than simple occultism and magic as usually perceived.

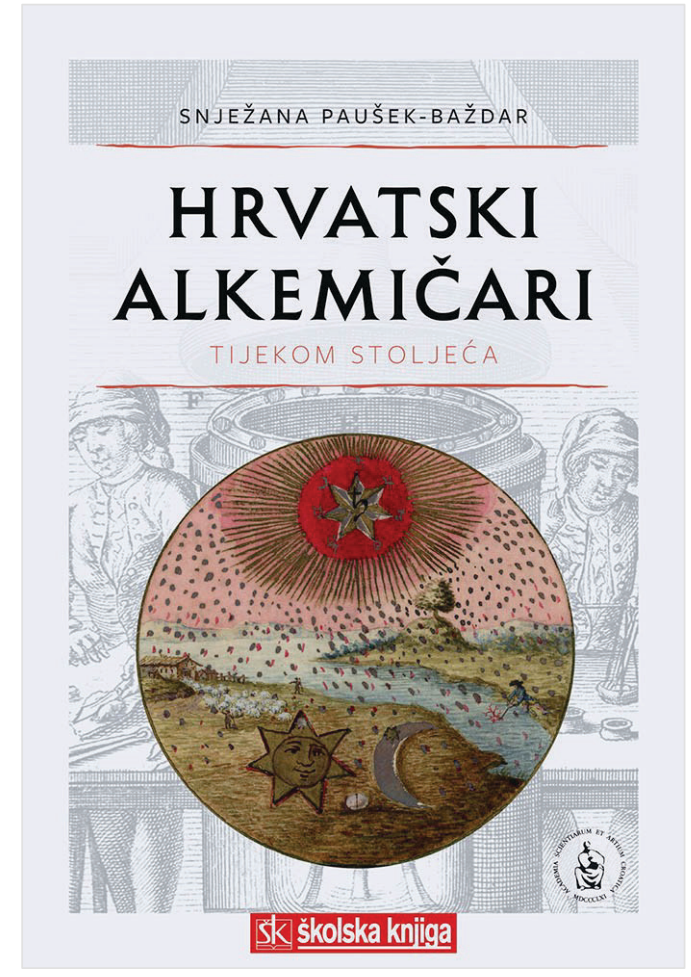

Thus speaking in modern terms the alchemy might be compared to the search of so-called "God particle" (i.e. the Higgs boson), which implies that throughout centuries the scientific method has changed however the main goal of science has remained the same. Since alchemy encompasses science, art, philosophy, religion and psychology, the elements of which can be categorized as either known; unknown which may once become known; or entirely incomprehensible, it also encompasses the virtue of conversion, 
both in material and spiritual reality. Therefore alchemists sought to achieve not only physical perfection and harmony but also the nonphysical one, i.e. the achievement of "spiritual gold". The basic idea and motivation of the alchemists' theory has always been the same: the conversion of some less valuable item (either physical or spiritual) to something closer to perfection and in accordance with Platonism and Aristotelism the alchemists have believed that every matter in the world pursues a path towards its perfection. The gold is regarded as perfection of the material world, while on the same line the perfection of the spiritual world would be perfection of man - i.e. the "spiritual gold". However, according to alchemists, the perfection cannot be achieved without knowing the prime matter, which is the matter everything began of. This belief has led the alchemists to be very persistent, but also humble in their own way and in their accomplishment. All the alchemical recipes arise from the prime matter, and are taken with respect to the harmony of superlunary (celestial) and sublunary (earthly) world. The earthly world and the life of a man is a macro cosmos in small scale, where everything is related to everything and everything arises from "one". Hence "one" is everything, "one" becomes everything, and through "one" arises everything.

Following the introductory chapter on the roots and philosophy of the alchemical science, the author thoroughly explores and interprets the manuscripts and printed texts of the Croatian alchemists and evaluates their research in the context of their European contemporaries. It is shown that the views of some of the Croatian alchemists had a considerable reception in the European scientific circles of the past centuries and that the Croats in that sense have also taken part in the development of European science and civilization as a whole. Immediately after the introduction there is a text on alchemical experiments from the beginning of the $15^{\text {th }}$ century by the queen Barbara Celjska, who was the wife of the Croatian-Hungarian king Sigismund of Luxemburg, and the first female alchemist after Mary the Jewess from the $1^{\text {st }}$ century. In the basement of her castle in Samobor, Barbara allegedly formed a laboratory and practised alchemy. Although Barbara did not directly leave any written clues on her work, the author of the book has found a description of her experiments on copper transmutation in the work of German Benedictine Basilius Valentinus from the beginning of the $17^{\text {th }}$ century, who again has cited some lost earlier texts and folk legends (such as legend of Barbara as the "Black Queen"). Thus, her work as an alchemist remains controversial.

The first recognized natural scientist and philosopher within the European heritage in the book is Petar Bono, who was a city physicist, and in 1330 wrote the thesis entitled Pretiosa margarita novella (New Precious Pearl). Petar Bono worked within the frame of Christosophy, which compares the role of Christ in the spiritual world to the philoso- pher's stone in the material world. To explain nature of the philosopher's stone, he has used the analogy with than popular mercury-sulphur theory of the metal structure, by which he has perceived the philosopher's stone as a perfect unity of contradictions (the equilibrium of the cold and humid material properties with warm and dry ones). It is assumed that Daniel Istranin, who was a grammar professor also in Pula in $14^{\text {th }}$ century, was the predecessor of Petar Bono. Daniel wrote the 18 stanzas poem ("Canzona") on the philosopher's stone which was published in the proceedings of the transmutation texts in Venice at the end of the $16^{\text {th }}$ century. After analysing Daniel's Canzona, the author of the book shows that Daniel, unlike Petar Bono, in his alchemical work put an emphasize onto hermetic philosophy of joining similarities (grain gives birth to grain, man gives birth to man, so gold gives birth to gold) and hence assumes that one of the ingredients of the philosopher's stone must be gold. After twenty-five years of experimental work, he allegedly succeeded to make the stone by mixing mercury, gold and silver, and by invoking the help of Jesus Christ himself. Using the $1 \%$ of the reportedly created stone, he has made a life elixir.

Among other alchemists from the renaissance period the author also analyses the work of Ivan the prebendary in Zagreb, together with Federik Grisogono from Zadar and Giulio Camillo Delminio allegedly from Duvno. In the following chapters, the author studies work of Croatian alchemists from the $17^{\text {th }}$ to the $19^{\text {th }}$ century - Ivan Leopold Payer, Ignjat Martinović, Tomas Mikloušić, Philip Šufflay etc.; all the way to baron Lazar Hellenbach, who is considered the last Croatian alchemist. By reading about the work of these alchemists, it is possible to note that in the late renaissance the alchemy started to disintegrate into two streams. The prevailing stream has gradually rejected spiritual and philosophical elements of the alchemy and developed modern experimental chemistry methods, as well as pharmacy and medicine; while the other stream rejected experimental methods and has devoted exclusively to the spiritual aspect of alchemy, giving rise to magic and occultism.

In this book, the author presents the contribution of the Croats to the alchemy in the period of renaissance and later, while at the same time explains the role and importance of alchemy in the development of European science and civilization. The book is richly illustrated and, given the complexity of the subject, easy to read since it is written in a clear and comprehensible style. Given that alchemy emerged as a combination of science, philosophy and spirituality, the reader gets a new and very interesting insight into the way of human thinking. Therefore, the book is recommended for students and readers interested in the history and philosophy of science as well as for general public.

Astrid Gojmerac Ivšić 